\title{
Micropuncture Study of Albumin Transfer in Aminonucleoside Nephrosis in the Rat
}

\author{
John E. Lewy ${ }^{[26]}$ and Amadeo Pesce \\ Division of Pediatric Nephrology, Department of Pediatrics, Cornell University Medical College, New York, \\ New York, and Department of Medicine, Michael Reese Medical Center, Chicago, Illinois, USA
}

\section{Extract}

Albumin concentration in the proximal tubules of normal rats and rats with aminonucleoside nephrosis (AMN) was estimated by means of a sensitive radioimmunoassay. Nephrotic animals were studied at the onset of proteinuria and when the nephrotic syndrome was fully established. Albumin concentration in the proximal tubule of normal male rats averaged $2.5 \pm 0.3 \mathrm{mg} / 100 \mathrm{ml}$, whereas in early nephrotic rats it averaged $4.9 \pm 1.3 \mathrm{mg} / 100 \mathrm{ml}$ and in normal sized tubules of heavily proteinuric rats, $15.7 \pm 3.3 \mathrm{mg} / 100 \mathrm{ml}$. Control and early AMN animals appeared to have a relatively homogeneous population of surface convolutions, whereas the fully nephrotic rats had markedly increased heterogeneity. A population of dilated proximal tubules with an albumin concentration of $233.8 \pm 35.4 \mathrm{mg} / 100 \mathrm{ml}$ was found in this group. Albumin concentrations were randomly distributed throughout the proximal convolution of all three groups with no clear pattern of changing concentration along the nephron. The data demonstrate that enhanced glomerular permeability to albumin occurs in the experimental nephrotic syndrome in the rat.

\section{Speculation}

Early proximal tubular albumin concentrations are increased in aminonucleoside nephrosis in the rat, which indicates that there is an increased glomerular permeability to albumin in this disease. Absolute amounts of albumin leaving the end of the proximal convolution are increased over controls. Increased albumin excretion in these animals may be accounted for, in part, by increased glomerular permeability for albumin.

\section{Introduction}

The origin of the albuminuria of the nephrotic syndrome remains a perplexing problem. The relative importance of increased glomerular filtration of albumin and/or decreased tubular reabsorption or tubular secretion have been debated. The development of an assay system sensitive and specific enough to measure the small quantities of albumin present in the proximal tubule of the rat has made reexamination of this problem feasible. A number of authors have previously estimated the concentration of total protein or albumin in the proximal tubule of normal rats $[1,10,16$, 19] and dogs [4] and protein concentration along the nephron in proteinuric rats $[2,15]$. This study was designed to gain further information regarding the concentration and handling of albumin along the proximal tubule of the normal rat and the rat with aminonucleoside nephrosis by means of a sensitive radioimmunoassay [17]. 


\section{Methods}

Nephrosis was produced in male Sprague Dawley albino rats which weighed $150-200 \mathrm{~g}$ by the intravenous administration of $100 \mathrm{mg} / 100 \mathrm{~g}$, body wt, of an aminonucleoside of puromycin, 6-dimethyl-9-(3'-amino-3'deoxy- $\beta, \mathrm{D}$ ribofuranosyl purine $[7,13]$. Micropuncture experiments were carried out on 17 animals 96 and 144 hr after the injection of aminonucleoside and in $\mathbf{5}$ animals 4 days after the intravenous injection of saline (controls). By $96 \mathrm{hr}$ after injection of aminonucleoside, a morphologic and biochemical lesion was identifiable $[22,23]$. Proteinuria had begun but was mild. There had been no weight gain and no observable edema. There was no ascites and gross examination of the kidney revealed that surface nephrons are uniform in appearance. At $144 \mathrm{hr}$ ascites was present, proteinuria was heavy, and surface nephrons varied in appearance. At this stage, two major populations of tubules could be observed, the first appearing normal and the second widely dilated.

Anesthesia was induced by intraperitoneal injection of Inactin, 90-100 mg/kg, body wt. The animal was placed on a thermostatically controlled animal table and the left and right external jugular veins were cannulated as was the trachea. The left kidney was exposed and freed from the adrenal gland and perirenal fat. The renal capsule was left intact. The kidney was placed in a Lucite cup in vivo and covered with a continuous drip of light mineral oil warmed to $37-38^{\circ}$. The ureter was cannulated with PE no. 10 tubing. Physiologic saline (1\% of body weight) was injected intravenously to replace surgical fluid losses. This was followed by a continuous infusion of saline at a rate of $0.01 \mathrm{ml} / \mathrm{min}$. The fluid contained ${ }^{14} \mathrm{C}$-labeled inulin in sufficient quantities to deliver $30 \mu \mathrm{Ci} / \mathrm{hr}$. At least 30 min were allowed for equilibration in extracellular fluid before beginning collections. Serial clearance periods were obtained throughout the experiment. Blood samples (approximately $100 \mu \mathrm{l}$ ) were taken from the warmed tail vein. Free flow micropuncture was performed with micropipettes with sharpened tips of 10-12 $\mu$ (OD). Light mineral oil stained with Sudan black was used to block the tubule distal to the site of collection. Great care was taken so that the puncture of each nephron was performed with the least possible trauma. Tips were very carefully sharpened and only those nephrons in which the tip entered the nephron without depressing the kidney surface were sampled. Only nephrons in which no blood vessel was seen traversing the surface were used. If any leakage was noted around the puncture site, the sample was discarded. All samples were collected by spontaneous flow into the pipette and the collection was discarded if the oil block moved distally or if spontaneous inflow ceased. Proximal tubular transit time was estimated by observing the passage of lissamine green [18] to the tip of the collecting pipette. In control and 92- -96-hr animals, the passage time of lissamine green to the collecting pipette was divided by the transit time to the end of the proximal convolution as a rough estimate of distance from the glomerulus. In 144-hr animals the point of puncture was determined by microdissection of latex-injected tubules. Inulin was measured by liquid scintillation photometry. Total protein in serum and urine was estimated by the method of Lowry et al. [14].

A sensitive radioimmunoassay was developed for the measurement of albumin in serum, urine, and tubular samples [17]. Preparation of rat albumin for labeling with 125 I was performed by subjection of commercial rat albumin [24] to electrophoresis on the Brinkman electrophorator. No impurities were then detectable by immunoelectrophoresis. Antibody was prepared in rabbits to preparations of albumin made by DEAE-cellulose chromatography. This antibody showed a major albumin band and a minor contaminating band in the $\alpha_{1}$ region. The purified antigen was labeled with ${ }^{125} \mathrm{I}$ using chloramine $T$. The use of the highly purified albumin as labeled material made it possible to ignore the small impurity of the antibody. Aliquots $(0.2 \mathrm{ml})$ of rabbit anti-rat albumin antiserum diluted in potassium phosphate buffer were placed in polystyrene tubes. The tubes were incubated overnight at $4^{\circ}$. The next morning the tubes were washed several times with saline and then $0.2 \mathrm{ml} 1 \%$ bovine serum albumin (BSA) in 0.1 $\mathrm{M}$ potassium phosphate buffer, $\mathrm{pH}$ 7.0, was added. Samples from nephron puncture or standard rat albumin solutions were transferred to a constant bore capillary, measured, and then delivered into the antibody-coated tubes containing $0.2 \mathrm{ml}$ phosphate buffer and 1\% BSA. Phosphate buffer-BSA (0.1 ml) containing $1 \mathrm{ng}$ labeled rat albumin was added next. The tubes were incubated overnight in the cold, counted, washed several times with saline, and then recounted. The percentage of labeled albumin bound to antibody was calculated from the amount of labeled albumin which adhered to the tube and total amount of radioactivity in the same tube before washing. The standard solutions used were $1,2,5$, and $10 \mathrm{mg} / 100 \mathrm{ml}$ solutions of Pentex crystalline rat albumin dissolved in 
0.1 M potassium phosphate buffer, $\mathrm{pH}$ 7.0. Approximately $100 \mathrm{nl}$ corresponding to $1,2,5$, and $10 \mathrm{ng}$ albumin were measured in the constant bore capillary and then added to the tubes. Each standard was repeated five times. In order to assess any loss of albumin during the microtransfer step or in the glassware, BSA-buffered samples of larger volume were also assayed. The standards not microtransferred were prepared by dissolving $1 \mathrm{mg}$ rat albumin [24] in $1 \mathrm{ml}$ $0.9 \%$ saline containing $0.1 \%$ sodium azide as a preservative. Serial dilutions of $1 / 100$ to $1 / 100,000$ were made in $1 \%$ BSA in $0.1 \mathrm{~m}$ potassium phosphate buffer. Samples of 5, 10, and $20 \mu \mathrm{l}$ of these working dilutions were added to the assay tubes previously coated with antibody. An example of the standard curve of both assay maneuvers is presented in Fig. 1 . There is a constant loss of albumin in the microtransfer system. In $45 \mathrm{sam}$ ples assayed, containing 1, 2, 5 and $10 \mathrm{ng}$, albumin loss averaged $18.9,15.5,14.7$, and $18.1 \%$, respectively. Since there is a loss of albumin by passage through the micropuncture apparatus, all tubular samples were calculated from curves obtained by plotting standard albumin solutions microtransferred with each set of samples against the percentage labeled albumin remaining in each tube after washing.

In order to test the sensitivity of the assay in detection of serum albumin in urine, the following experiment was carried out. Rat urine was diluted $1 / 50$ in $1 \%$ BSA-phosphate buffer and 10 samples were analyzed in the usual manner. This yielded an average of $15 \mathrm{ng}$ albumin (range 12-19 ng). Rat urine was then doped with the rat albumin used in the standard curve $(1 \mathrm{mg} / \mathrm{ml}$ ) by the addition of either 0.05 or $0.20 \mathrm{ml}$ albumin to the urine. The urine was again diluted $1 / 50$ and $10 \mu 1$ samples were assayed. This yielded rat urine with an extra 10 or $33 \mathrm{ng}$ of albumin per assay sample. These were placed in 20 different sample tubes and analyzed. Samples with $10 \mathrm{ng}$ added averaged 27 ng (range 25-30) with an expected level of $25 \mathrm{ng}$ and samples with $33 \mathrm{ng}$ averaged $44 \mathrm{ng}$ (range 42-49) with an expected level of $48 \mathrm{ng}$.

To test the effect of changing concentrations, the rat urine described above was diluted 1/5, 1/10, 1/25, 1/ $50,1 / 100$ and $1 / 200$ with the standard BSA-phosphate buffer. Samples of 10 and $20 \mu \mathrm{l}$ were taken from each dilution and the assay was analyzed in the normal manner. The difference between the lowest and highest amounts of urine was 80 -fold. The assay curve made by dilution of urine was superimposable on that of the standard assay curve. Thus, neither increasing

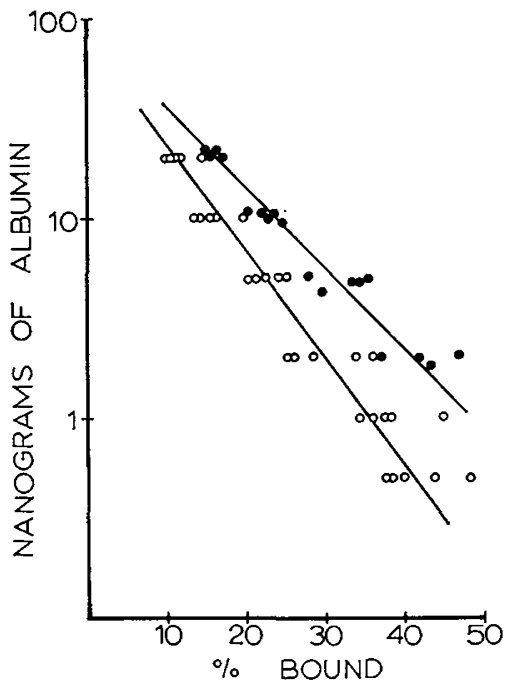

Fig. 1. The percentage of ${ }^{125}$ I-labeled rat albumin bound to antibody is plotted against the quantity of unlabeled standard rat albumin added to the antibody containing tube. $O$ : samples aspirated with lambda pipettes and added directly to the tubes containing antibody and phosphate buffered bovine serum albumin. -: albumin standards which are microtransferred into similar tubes.

the concentration of rat urine nor adding albumin to the urine sample changed the recovery of the albumin in the samples.

\section{Results}

Urine volume in five control animals during the last $24 \mathrm{hr}$ on balance before micropuncture study averaged $16.9 \pm 3.5 \mu \mathrm{l} / \mathrm{min}$. Urine volume after Inactin anesthesia and overnight food restriction was $3.0 \pm 0.6$ $\mu \mathrm{l} / \mathrm{min}$ (Table I). Total urinary protein was $5.2 \mu \mathrm{g} /$ min, whereas urinary albumin averaged $1.4 \mu \mathrm{g} / \mathrm{min}$. Total serum protein of these animals averaged $5.8 \mathrm{~g} /$ $100 \mathrm{ml}$ and albumin $3.0 \mathrm{~g} / 100 \mathrm{ml}$. Forty-seven proximal tubular punctures contained an average albumin concentration of $2.5 \mathrm{mg} / 100 \mathrm{ml}$ (Tables I and II). There was a random distribution of albumin concentration within the proximal tubule (Fig. 2) with an average of $2.9 \mathrm{mg} / 100 \mathrm{ml}$ in the early proximal, 2.5 $\mathrm{mg} / 100 \mathrm{ml}$ in the midproximal, and $2.4 \mathrm{mg} / 100 \mathrm{ml}$ in the late proximal tubule. It is pertinent to note the handling of those samples with albumin concentrations below the level of detection. All samples were analyzed independently of volume. Inasmuch as the level of detection was $1 \mathrm{ng}$ absolute albumin content, samples which contained less than $\mathrm{l} \mathrm{ng}$ and were smaller than $100 \mathrm{nl}$ in size (22 samples) were not used 
Table $I$. Urinary protein excretion and proximal tubular albumin concentrations in control and aminonucleoside rats ${ }^{1}$

\begin{tabular}{|c|c|c|c|}
\hline & \multirow{2}{*}{ Control } & \multicolumn{2}{|c|}{ Aminonucleoside } \\
\hline & & $92-96 \mathrm{hr}$ & $142-144 \mathrm{hr}$ \\
\hline No. of animals & 5 & 7 & 10 \\
\hline Urine volume, $\mu 1 / \mathrm{min}$ & $3.0 \pm 0.6$ & $2.4 \pm 0.3$ & $3.9 \pm 0.3$ \\
\hline Urine protein, $\mu \mathrm{g} / \mathrm{min}$ & $5.2 \pm 1.7$ & $22.8 \pm 7.7$ & $168.9 \pm 32.2$ \\
\hline Urine albumin, $\mu \mathrm{g} / \mathrm{min}$ & $1.4 \pm 0.8$ & $8.9 \pm 2.2$ & $58.2 \pm 13.8$ \\
\hline Plasma protein, $\mathrm{g} / 100 \mathrm{ml}$ & $5.8 \pm 0.1$ & $5.2 \pm 0.1$ & $4.2 \pm 0.2$ \\
\hline Plasma albumin, $\mathrm{g} / 100 \mathrm{ml}$ & $3.0 \pm 0.2$ & $2.4 \pm 0.2$ & $1.3 \pm 0.3$ \\
\hline \multicolumn{4}{|l|}{ Proximal tubular albumin } \\
\hline $\begin{array}{l}\text { Normal sized tubules, } \mathrm{mg} / 100 \mathrm{ml} \\
\text { Dilated tubules, } \mathrm{mg} / 100 \mathrm{ml}\end{array}$ & $2.5 \pm 0.3(47)$ & $4.9 \pm 1.3(35)$ & $\begin{aligned} 15.8 & \pm 3.3(32) \\
233.8 & \pm 35.4(25)\end{aligned}$ \\
\hline Surface fluid albumin, $\mathrm{mg} / 100 \mathrm{ml}$ & $44.1 \pm 12.4(8)$ & $75.4 \pm 17.8(13)$ & $45.0 \pm 14.1(19)$ \\
\hline
\end{tabular}

${ }^{1}$ Data are expressed as means \pm SEM. The number of observations is shown in parentheses.

Table II. Albumin concentration in early, mid, and late proximal convoluted tubule

\begin{tabular}{|c|c|c|c|c|c|c|c|c|}
\hline & Control & $\begin{array}{l}\text { No. } \\
\text { obser- } \\
\text { vations }\end{array}$ & $\begin{array}{l}\text { AMN, } \\
92-96 \mathrm{hr}\end{array}$ & $\begin{array}{l}\text { No. } \\
\text { obser- } \\
\text { vations }\end{array}$ & $\begin{array}{c}\mathrm{AMN} \\
142-144 \mathrm{hr} \\
\text { normal sized }\end{array}$ & $\begin{array}{c}\text { No. } \\
\text { obser- } \\
\text { vations }\end{array}$ & $\begin{array}{l}\text { AMN, } \\
142-144 \mathrm{hr}, \\
\text { dilated }\end{array}$ & $\begin{array}{l}\text { No. } \\
\text { obser- } \\
\text { vations }\end{array}$ \\
\hline \multicolumn{9}{|c|}{$\begin{array}{l}\text { Tubular albumin, } \mathrm{mg} / 100 \\
\mathrm{ml}\end{array}$} \\
\hline Early proximal & $2.9 \pm 0.6$ & 10 & $3.6 \pm 1.8$ & 10 & $10.3 \pm 3.0^{2}$ & 12 & $293.0 \pm 77.5^{3}$ & 6 \\
\hline Midproximal & $2.5 \pm 0.6$ & 17 & $6.9 \pm 3.2$ & 12 & $18.4 \pm 5.8^{2}$ & 12 & $260.9 \pm 128.8^{3}$ & 5 \\
\hline Late proximal & $2.4 \pm 0.4$ & 20 & $3.9 \pm 1.1$ & 13 & $20.5 \pm 8.8^{2}$ & 8 & $272.9 \pm 21.3^{3}$ & 2 \\
\hline Total & $2.5 \pm 0.3$ & 47 & $4.9 \pm 1.3$ & 35 & $15.8 \pm 3.3^{3}$ & 32 & $233.8 \pm 35.4^{3}$ & 25 \\
\hline
\end{tabular}

1 AMN : Aminonucleoside nephrosis.

${ }^{2} P<0.05$ (versus control).

${ }^{3} P<0.01$ (versus control)

in the calculations for Tables I and II. All samples with albumin content below $1 \mathrm{ng}$ but which were 100 $\mathrm{nl}$ or larger in size were included and listed as $1 \mathrm{mg} /$ $100 \mathrm{ml}$. One hundred nanoliters of tubular fluid with an albumin concentration of $1 \mathrm{mg} / 100 \mathrm{ml}$ would yield $1 \mathrm{ng}$ absolute albumin content. Assigning a value of 1 $\mathrm{mg} / 100 \mathrm{ml}$ to such samples should represent a maximum albumin concentration. Thus, the average concentration of albumin of $2.5 \mathrm{mg} / 100 \mathrm{ml}$ represents a maximal figure. Tubular fluid to plasma $(\mathrm{TF} / \mathrm{P})$ inulin ratios at the end of the proximal convolution in control animals averaged $1.91 \pm 0.12$ (12 observations).

In order to assess the role of contamination from surface fluid, a number of samples of fluid which could be aspirated from the surface of the kidney but were below the oil layer were examined. In control animals, this averaged $44.1 \pm 12.4 \mathrm{mg} / 100 \mathrm{ml}$ (albumin concentration).

Urine volume during the last $24 \mathrm{hr}$ of balance in seven animals which were studied 92-96 hr after aminonucleoside injection was $10.0 \pm 1.6 \mu \mathrm{l} / \mathrm{min}$. After induction of anesthesia, urine volume was $2.4 \mu \mathrm{l} / \mathrm{min}$ (Table I). Urinary protein averaged $22.8 \mu \mathrm{g} / \mathrm{min}$ and urinary albumin $8.9 \mu \mathrm{g} / \mathrm{min}$. Plasma protein in these animals was $5.2 \mathrm{~g} / 100 \mathrm{ml}$ with a plasma albumin of 2.4 $\mathrm{g} / 100 \mathrm{ml}$. Proximal tubular albumin concentration averaged $4.9 \mathrm{mg} / 100 \mathrm{ml}, 3.6 \mathrm{mg} / 100 \mathrm{ml}$ in the early proximal, $6.9 \mathrm{mg} / 100$ in the midproximal, and 3.9 $\mathrm{mg} / 100 \mathrm{ml}$ in the late proximal tubule (Table II). The rise in the middle of the proximal tubule was primarily due to one measurement of $40 \mathrm{mg} / 100 \mathrm{ml}$ (Fig. 2). This measurement was considerably higher than others in the 92- -96-hr group and may represent unrecognized contamination. However, since the tip entered the tubule without difficulty, the collection was uneventful, and no contamination was noted, the measurement was included. The distribution of albumin concentrations was again random although a wider range of concentration is noted (Fig. 2). Surface fluid albumin was $75.4 \pm 17.8 \mathrm{mg} / 100 \mathrm{ml}$. The ratio of $\mathrm{TF} / \mathrm{P}$ inulin at the end of the proximal convolution was $2.80 \pm 0.12$ (25 observations). In the 10 animals studied 142-144 hr after aminonucleoside injection, urine volume during the last day of balance was $9.2 \pm$ $1.8 \mu \mathrm{l} / \mathrm{min}$ and during the experiment was $3.9 \pm 0.3$ $\mu \mathrm{l} / \mathrm{min}$ (Table $\mathrm{I}$ ). Urinary protein averaged $168.9 \mu \mathrm{g} /$ 
min and urinary albumin $58.2 \mu \mathrm{g} / \mathrm{min}$. Plasma protein in these animals had a mean of $4.2 \mathrm{~g} / 100 \mathrm{ml}$ and plasma albumin $1.3 \mathrm{~g} / 100 \mathrm{ml}$. There were at least two populations of surface proximal tubules. Of the nephrons studied, 50-70\% appeared to be normal in size. Although transit times to the end of the proximal convolution of these nephrons were longer $(20.7 \pm 1.4$ sec) than in control $(9.3 \pm 0.5 \mathrm{sec})$ and $96-\mathrm{hr}$ animals $(13.0 \pm 0.9 \mathrm{sec})$, there was a clear and distinct movement through the nephron. In these nephrons the proximal tubular albumin averaged $15.8 \mathrm{mg} / 100: 10.3 \mathrm{mg} / 100$ $\mathrm{ml}$ in the early proximal, $18.4 \mathrm{mg} / 100 \mathrm{ml}$ in the midproximal, and $20.5 \mathrm{mg} / 100 \mathrm{ml}$ in the late portion of the proximal convolution. Once again, there was no detectable change in the distribution of albumin concentrations along the nephron. The TF/P inulin concentration at the end of the proximal convolution was $2.73 \pm 0.06$ (six observations). The second population of tubules appeared to be dilated with tubular lumina approximately twice the size of the "normal" tubules. These tubules were filled with fluid but movement was quite slow and transit time could not be accurately measured. Lissamine green did appear gradually in these tubules after intravenous injection. Albumin concentration averaged $233.8 \mathrm{mg} / 100 \mathrm{ml}$ in these nephrons: $293 \mathrm{mg} / 100 \mathrm{ml}$ in early, $261 \mathrm{mg} / 100 \mathrm{ml}$ in mid, and $273 \mathrm{mg} / 100 \mathrm{ml}$ in late proximal tubules (Table II). Surface fluid albumin was sampled and averaged $45.0 \mathrm{mg} / 100 \mathrm{ml}$.

\section{Discussion}

It has been suggested that increased glomerular filtration of protein is the initiating lesion in the nephrotic syndrome $[3,5,6,9,15,20,21]$, but direct evidence for this has been lacking. In a recent study of the ultrastructure of the glomerulus in aminonucleoside nephrosis, Venkatachalam and coworkers [21] have reported that horseradish peroxidase (molecular weight 40,000 ) crosses the glomerular capillary barrier into the urinary space in nephrotic rats. In addition, they have reported that bovine liver catalase (mol wt $240,000)$ also crosses into the urinary space in aminonucleoside nephrosis, but not through normal glomeruli [20]. In one previous investigation of tubular protein in the experimental nephrotic syndrome [2], proximal tubular protein concentration was not found to be increased in the rat 3-4 days after the injection of aminonueleoside. A more recent study, however [15], has shown an increase in proximal albumin concentration 4 days after injection. The present study shows a
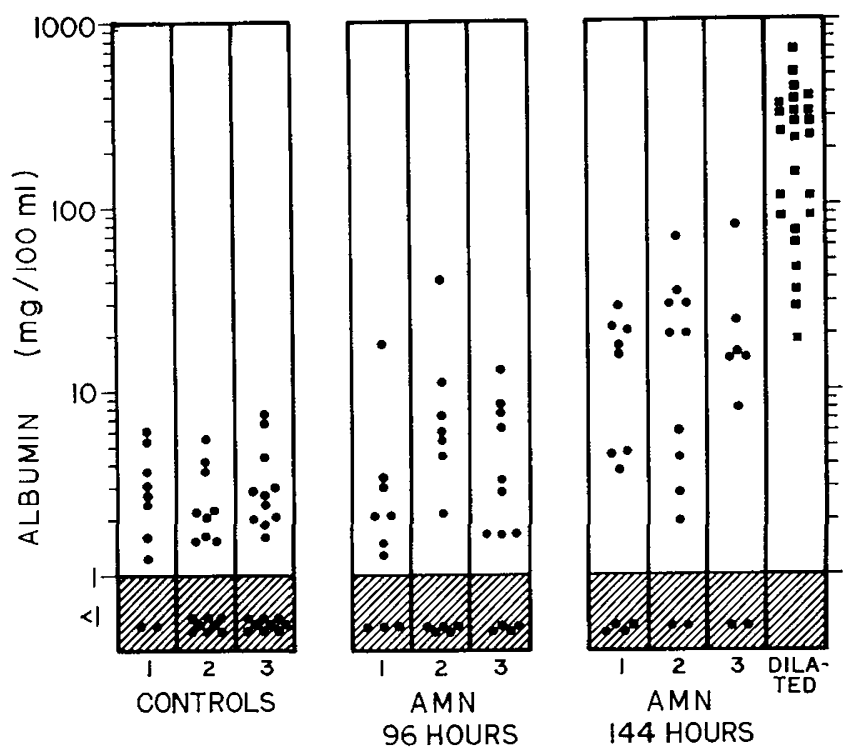

Fig. 2. Albumin concentration is illustrated relative to the site of puncture along the proximal tubule. The numbers on the abscissa refer to the early, mid, and latc portion of the proximal convolution. Dilated identifies those tubules in the rat $144 \mathrm{hr}$ after aminonucleoside injection that were widely dilated. The shaded area contains those samples that were $100 \mathrm{nl}$ or more in size but in which the albumin concentration was less than $1 \mathrm{mg} /$ $100 \mathrm{ml}$. $A M N$ : Aminonucleoside nephrosis.

small but not significantly increased concentration of proximal tubule albumin 4 days after aminonuceloside injection. Although the mean concentration of albumin is increased in these animals, the scatter is great and 12 of 35 proximal tubular punctures reveal an albumin concentration of $1 \mathrm{mg} / 100 \mathrm{ml}$ or less. In the more fully developed nephrotic syndrome (6 day), many of the normally sized tubules and all of the dilated tubules reveal a significantly enhanced albumin concentration (Table II). The dilated tubules had very sluggish flow, however, and may contribute relatively little to final urine formation. The role of contamination in the nephron puncture samples must receive close attention. Since the concentration of albumin in the peritubular capillaries is much greater than that in the proximal tubular lumen, even a small amount of contamination could account for the total amount of albumin found in the tubules of control and early aminonucleoside rats. Great care was taken to minimize contamination (see Methods). Nonetheless, a small unrecognized contamination cannot be totally excluded. In the 142- -144-hr aminonucleoside animal this type of contamination seems particularly unlikely in those nephrons that were widely dilated and had high albumin concentrations. These nephrons were 
particularly easy to puncture and only $15-30 \mathrm{sec}$ were necessary for collection of the sample because the protein concentration was quite high. Plasma albumin concentration averaged $1.3 \mathrm{~g} / 100 \mathrm{ml}$. There would, therefore, have had to have been plasma contamination of approximately $20 \%$ to account for the albumin concentration found. The second potential source of contamination is surface fluid, the small amount of fluid on the surface of the kidney moving into the tubule and then into the collecting pipette. In both the control and 6-day aminonucleoside animal the concentration of albumin on the surface averaged $45 \mathrm{mg} /$ $100 \mathrm{ml}$ and in the 4 -day rats, $75 \mathrm{mg} / 100 \mathrm{ml}$. In the control animals a 5-10\% contamination would be necessary to account for the albumin concentration found. In the dilated tubules of the 6-day aminonucleoside animal, such a contamination would have decreased rather than increased the albumin concentration.

In order to speculate on whether the increased glomerular permeability to albumin demonstrated in rats $144 \mathrm{hr}$ after the injection of aminonucleoside contributes to the albuminuria observed, data on fluid transfer are needed.

In a study of glomerulotubular interrelationships in this disease [11, 12], we measured single nephron glomerular filtration rate (GFR) and absolute reabsorption to the end of the proximal convolution. The following equations were employed to estimate albumin filtration and reabsorption: $(1)$ single nephron GFR $\times$ early proximal tubular albumin concentration $=$ filtered albumin; (2) end-proximal collection volume = amount of fluid escaping reabsorption in the proximal convolution. (3) (2) $\times$ end-proximal albumin concentration = amount of albumin escaping reabsorption in the proximal convolution.

In five control rats single nephron GFR was $32.6 \pm$ $2.8 \mathrm{nl} / \mathrm{min}$. Early proximal tubular albumin concentration was $2.9 \pm 0.6 \mathrm{mg} / 100 \mathrm{ml}$. This would yield a mean of $0.95 \mathrm{ng}$ filtered albumin $/ \mathrm{min}$. Single nephron GFR was $18.4 \pm 2.5 \mathrm{nl} / \mathrm{min}$ in normal sized tubules in seven rats $144 \mathrm{hr}$ after aminonucleoside injection. An early proximal tubular albumin concentration of $10.3 \pm 3.0 \mathrm{mg} / 100 \mathrm{ml}$ yields $1.89 \mathrm{ng}$ filtered albumin/ $\min$.

In control rats end proximal collection volume was $18.3 \pm 1.9 \mathrm{nl} / \mathrm{min}$. Late proximal albumin concentration was $2.4 \pm 0.4 \mathrm{mg} / 100 \mathrm{ml}$; therefore, $0.44 \mathrm{ng}$ albu$\mathrm{min} / \mathrm{min}$ escape proximal reabsorption. In aminonucleoside rats $5.8 \pm 0.7 \mathrm{nl} / \mathrm{min}$ left the proximal convolution. Late proximal albumin concentration was
$20.5 \pm 8.8 \mathrm{mg} / 100 \mathrm{ml}$. In this segment, $1.18 \mathrm{ng}$ albu$\mathrm{min} / \mathrm{min}$ escape reabsorption.

The above calculations are speculative inasmuch as the albumin concentrations and fluid transfer data are not paired data. They suggest, however, that increased distal delivery of albumin does occur in aminonucleoside nephrosis. Paired data are needed to assess more precisely the relative role of increased filtration of albumin and incomplete proximal tubular reabsorption of this increased load.

\section{Summary}

This study demonstrates that an increase in glomerular permeability for albumin does occur in aminonucleoside nephrosis. Nephron heterogeneity characterizes the latter stages of the disease. There is no evidence for a changing concentration of albumin with passage along the proximal convolution in either normal or aminonucleoside rats, but scatter in the data suggests that serial punctures along the same nephron are required to quantitate single nephron albumin reabsorption. Comparison with data on fluid reabsorption indicates that increased distal delivery of albumin may contribute to the proteinuria of the fully developed aminonucleoside nephrotic syndrome.

\section{References and Notes}

1. Carone, F. A., Post, R. S., and Banks, D. B.: Micropuncture study of albumin excretion in the normal rat. Amer. J. Pathol., 55: A19 (1968).

2. Carone, F. A., and Von HaAm, E. V. H.: Micropuncture study of protein excretion in normal and proteinuric rats. Clin. Res., 13: 302 (1965).

3. Chinard, F. P., Lauson, H. D., Eder, H. A., Greif, R. L., and HrLler, A.: A study of the mechanism of proteinuria in patients with the nephrotic syndrome. J. Clin. Invest., 33: 621 (1954).

4. Dirks, J. H., Clapp, J. R., ANd Berliner, R. W.: The protein concentration in the proximal tubule of the dog. J. Clin. Invest., 43: 916 (1964).

5. Eder, H. A., lauson, H. D., Chinard, F. P., Grief, R. L., Corzias, G. C., and VAN Slyke, D. D.: A study of the mechanisms of edema formation in patients with the nephrotic syndrome. J. Clin. Invest., 33: 636 (1954).

6. Farquhar, M. G., and Palade, G. E.: Glomerular permeability. II. Ferritin transfer across the glomerular capillary wall in nephrotic syndrome. J. Exp. Med., 114: 699 (1961).

7. Frenk, S., Antonowicz, I., Craig, J. M., and Metcoff, J.: Experimental nephrotic syndrome induced in rats by aminonucleoside: Renal lesions and body electrolyte composition. Proc. Soc. Exp. Biol. Med., 89: 424 (1955).

8. Harkin, J. C., and Recant, L.: Pathogenesis of experimental nephrosis. Electron microscopic observations. Amer. J. Pathol., 36: 303 (1960). 
9. Kalant, N., Das Gupta, D., Despointes, R., and Giroud, C. J. P.: Mechanisms of edema in experimental nephrosis. Amer. J. Physiol., 202: 91 (1962).

10. Leber, P. D., AND MARSh, D. J.: Micropuncture study of concentration and fate of albumin in rat nephron. Amer. J. Physiol., 219: 358 (1970).

11. LEWY, J. E.: Micropuncture study of glomerulotubular balance in early aminonucleoside nephrosis in the rat (in press).

12. LEWY, J. E.: Unpublished data.

13. LONGNEGKER, D. S.: Organ distribution of puromycin in rats. A possible basis for selective cytotoxicity. Lab. Invest., 22: 400 (1970).

14. Lowry, O. H., Rosebrough, N. J., Farr, A. L., and Randall, R. J.: Protein measurement with the Folin phenol reagent. J. Biol. Chem., 193: 265 (1951).

15. OKen, D. E., Cores, S. C., ANd Mende, C. W.: Micropuncture study of tubular transport of albumin in rats with aminonucleoside nephrosis. Kidney Int., $1: 1$ (1972).

16. Oken, D. E., and Flamenbaum, W.: Micropuncture studies of proximal tubule albumin concentrations in normal and nephrotic rats. J. Clin. Invest., 50: 1498 (1971).

17. Pesce, A. J., Galzurus, M., and Lewy, J. E.: The determination of nanogram amounts of rat albumin by radioimmunoassay. Microchem. J., 17: 327 (1972).

18. Sreinhausen, M.: Ein Methode zur Differenzierung proximaler und distaler Tubuli der Nierenrinde von Ratten in vivo und ihre Anwendung zur Bestimmung tabularer Stromungeschwindigkeiten. Pfluegers Arch. Gesamte Physiol. Menschen Tiere, 277: 23 (1963).
19. Van Liew, J. B., Buentig, W., Stolte, H., and Boylan, J. W.: Protein excretion: micropuncture study of rat capsular and proximal tubule fluid. Amer. J. Physiol., 219: 299 (1970).

20. Venkatachalam, M. A., Cotran, R. S. and Karnovsky, M. $\mathrm{J}$ : An ultrastructural study of glomerular permeability in aminonucleoside nephrosis using catalase as a tracer protein. J. Exp. Med., 132: 1168 (1970).

21. Venkatachalam, M. A., Karnovsky, M. J., and Cotran, R. S.: Glomerular permeability: Ultrastructural studies in experimental nephrosis using horseradish peroxidase as a tracer. J. Exp. Med., 130: 381 (1969).

22. Vernier, R. L., Papermaster, B. W., and Good, R. A.: Aminonucleoside nephrosis. I. Electron microscopic study of the renal lesion in rats. J. Exp. Med., 109: 115 (1959).

23. Yoshida, T., and Metcoff, J.: A metabolic basis of aminonucleoside nephrosis. Effect of aminonucleoside (AMN) on oxidative phosphorylation (OP) at the substrate level. J. Pediat., 67: 917 (1965)

24. Pentex, Miles Laboratory, Elkhart, Indiana.

25. Dr. J. E. Lewy was supported by Grant no. AM14869, National Institutes of Health; Dr. A. Pesce was supported by Grants nos. AM12330 and AM10314, National Institutes of Health. Dr. A. Pesce is an Established Investigator, American Heart Association.

26. Requests for reprints should be addressed to: JoHN E. Lewy, M.D., Division of Pediatric Nephrology, Department of Pediatrics, Cornell University Medical College, 525 E. 68th St., New York, N.Y. 10020 (USA).

27. Accepted for publication January 4, 1973. 